\title{
BARNa Szamosi
}

Public Health Concerns Regarding Reproduction Structured by Race/ Ethnicity and Class during State Socialism in Hungary

Pro\&Contra 3

No. 1 (2019) 47-66. 



\begin{abstract}
This paper describes the means by which medical professionals of the socialist period integrated interwar public hygiene practices into the health management of gypsies from the perspective of the public health interest of the majority. In these practices, ethnic/racial stereotypes shaped public health action. Public-health officials justified these actions on the basis of their fear that gypsies would spread diseases if their hygiene issues were not controlled. A further development occurred in the discourse when gypsy ethnic identity came to be recognized as an important statistical variable in determining healthy birth rates. Regarding this question, it will be demonstrated that ethnic identity as a variable, appeared in the medical discourse as a problem that offset the overall reproductive statistics of the state. It is argued that the medical professional discourse with its arguments, practices, and measures, point towards a continuity between the interwar and socialist periods' public health regarding racial thinking.
\end{abstract}

Keywords: interwar period, eugenics, public health, socialism, Roma, gypsy, reproduction

\title{
Introduction
}

The public health discourse of Hungary during the 1950s prioritized contagious diseases with its main interest lay in finding ways to control these problems thereby safeguarding the interest of the majority. In this paper, I will describe the means by which medical professionals of the socialist period integrated interwar public hygiene practices into the health management of gypsies from the perspective of the public health interest of the majority ${ }^{1}$. In these practices, ethnic/racial stereotypes shaped public health action. Public-health officials justified these actions on the basis of their fear that gypsies would spread diseases if their hygiene issues were not controlled. Thus, the issue of ensuring good public-health standards was connected to environmental problems, class issues, and also to racial/ethnic identity. The aim was to develop the general public health conditions of the Hungarian gypsy communities, but these methods were not enabling but rather constraining and discriminatory measures. A further racial/ethnic issue occurred in this discourse when gypsy ethnic identity came to be recognized as an important statistical variable in determining healthy birth rates. Regarding this question, I will show that eth-

1 This study is a part of my PhD research project that was supported by the Central European University. Here I would like to express my gratitude towards my supervisors Andrea Pető and Judit Sándor who tirelessly helped the development of my work. And I would also like to thank two anonymous peer reviewers who gave feedback before the publication of this paper.

Pro\&Contra 1 (2019) 47-66. 
nic identity as a variable, appeared in the medical discourse framed as means to develop the overall reproductive statistics of the state. It was discovered that gypsy reproductive statistics offset regional and national results, thus in order to relieve the burden that these adverse results meant for the national healthcare system a better understanding of gypsy non-gypsy biological difference and about gypsy reproductive practices was needed. The intention was to help gypsy people to achieve healthier reproductive results and this was justified primarily from an economic perspective informed by eugenic ideas.

\section{Interwar Antecedents of Public Health Discourse on Gypsies}

As a result of the unsuccessful attempts to assimilate the gypsies and the growing influence of Nazi race theory, medical professionals began a discussion on public-health issues. Csaba Dupcsik reviewed the debate that took place in the Népegészségügy (Public Health) journal between 1939 and 1944. This particular journal is key to the understanding of the official state relation to the 'gypsy question' since it was the journal of the Ministry of Labor and Social Affairs until 1932 when it became the journal of the Ministry of Home Affairs. In the pages of this journal, health professionals aligned their views with the official state position on this question ${ }^{2}$. I will organize this short review around the issues analyzed by Dupcsik but place emphasis mainly on narratives of public-health risks and on reproduction.

During the 1920s negative attitudes towards wandering gypsies grew more pronounced. Perhaps as a result of the general racism towards gypsies, the Minister of Internal Affairs enacted a law in 1928 (257000/1928) that compelled the gendarmerie to conduct raids in which they rounded-up wandering gypsies to curb the danger that these people presented to the general public. Dupcsik in his work highlights that typical punishments were interning them for hard labor, forced relocation, and also public disinfection $^{3}$. The practice of public disinfection illustrates that the general sentiment towards the health standards of gypsies was extremely negative. Hungarian health professionals believed that these groups of people carried dangerous infectious diseases that had to be controlled regularly. This idea to control their diseases in a separate and radical way returned during the socialist period as I will elaborate later.

But it is also notable that these ideas that gypsies carried different diseases dangerous to non-gypsy people also contributed to the resistance that non-gypsies felt and

2 Csaba Dupcsik, A Magyarorsqági Cigányság Története. Történelem a Cigánykutatások Tükrében, 1890-2008 (Budapest: Osiris Kiadó, 2009), 119.

3 Dupcsik, A Magyarorsqági Cigányság Története, 103.

Pro\&Contra 1 (2019) 47-66. 
expressed when it came to the two groups living together. However, it was not only these imagined health problems that were widely shared by the health professionals who contributed to the discussion of the gypsy-question on the pages of Népegészségügy but also the idea that gypsy people were racially subordinate to non-gypsy Hungarians ${ }^{4}$. They disseminated the belief that assimilation was not viable therefore it was not desirable to foster the cohabitation of gypsy and non-gypsy Hungarians because that would inevitably lead to the degeneration of non-gypsies, and hence contribute to the degeneration of the Hungarian race.

The theme of degeneration surfaces more strongly in relation to the number of gypsy and non-gypsy descendants. The narrative, how reproduction is linked to gypsy behavior, fits neatly into an exclusionary discourse. It was argued that gypsies, because of their unproductive, lazy lifestyles are more sexually promiscuous; since they are not working in any socially productive sphere their only goal and pleasure in life is their sexuality. The difference between the reproductive growth of gypsy and non-gypsy communities, is explained by this previously described practice. According to Andor Olay, their racial characteristics predestine gypsies to such a way of life, therefore social assimilation is not a possible solution to the "gypsy-question" 5 . Instead of assimilation, assisted by reproductive interventions, healthcare professionals promoted the exact opposite.

They wanted to ensure that gypsy and non-gypsy people remained segregated because they believed that gypsies presented a grave biological threat to the Hungarian race. They approached the "gypsy-question" similarly to the "Jewish-question". Their aim was to manage these racial issues alike. For example, Ferenc Orsós, a physician and university professor, suggested prohibiting mixed marriages between gypsy and non-gypsy couples just as the third Jewish-law prohibited mixed marriages between Jewish and non-Jewish couples in 1941. Orsós differentiated between the two "questions" in terms of danger and class: he argued that while mixed Jewish marriages are dangerous biologically and politically for the upper classes, mixed gypsy marriages presented a danger to the working classes $^{6}$. In addition to these measures, the discussion was directed towards more radical control of the population.

In order to strengthen their standpoint, healthcare professionals participating in the debate drew on utilitarian ideas: they claimed that gypsies were not economically useful elements of the body politic therefore their medical care is pure loss without any profit. They sketched two directions to address the above issue. Similarly to their German coun-

4 Dupcsik, A Magyarországi Cigányság Története, 123-124.

5 Dupcsik, A Magyarországi Cigányság Története, 121.

${ }^{6}$ Dupcsik, A Magyarországi Cigányság Története, 93-94.

Pro\&Contra 1 (2019) 47-66. 
terparts, Hungarian race-theorists supported the forced relocation of Hungarian gypsies to Eastern territories. They believed that the expulsion of gypsies from Hungary and from Europe would solve the health problems presented. Another method that was suggested by the contributors was forced sterilization on the condition that relocation could not be achieved. From the authors of 16 articles - which was the complete Népegészségügy-debate -5 endorsed forced sterilizations, and the authors of 12 articles agreed that either relocation or internment to forced labor camps was the solution ${ }^{7}$. From these positions it is evident that health professionals embraced and endorsed the radical segregation of gypsies from non-gypsies for reproductive reasons as well as proposing to stop their reproduction through sterilization.

Neither of the above suggested reproductive interventions transpired, but the contribution, that is, the aim of healthcare professionals to shape the political discourse from their racially biased position based on stereotypes, is clearly visible in the debate. In this late eugenic era healthcare professionals - such as physicians, head physicians, nurses, researchers, and research assistants - actively engaged in shaping the discussion on how to improve the biological material of the Hungarian race. Their suggestions consisted in primarily negative eugenic interventions, along the lines of race, class, and gender, where gender meant the underlying principle in the control of heterosexual reproduction. In the following I will analyze the changes that took place during the socialist era in contrast to the events of the interwar period.

\section{Racial/ethnic Stereotypes that Shaped Public Health Discussions and Public Health Practices after 1948}

Perhaps one of the most important developments of the socialist era in contrast to the interwar period is that explicit racial discrimination became politically unacceptable from 1948, at least officially. This was evident in the official state discourse on problems related to education, criminal behavior, or public health as they were no longer explained through the language of biological essentialism which would explicitly support racial bias. However, there are plenty of cases to draw on to explain how racial/ethnic discrimination worked in the socialist Hungarian state.

7 Dupcsik, A Magyarországi Cigányság Története, 127.

Pro\&Contra 1 (2019) 47-66. 


\section{Legal Segregation: Black Identity Cards}

On 26 August 1953, the Political Committee of the Hungarian Workers Party decided to equip all Hungarian citizens with identity cards. Their reasons for introducing IDs were the following: (1) the Hungarian population would need fewer documents yearly; (2) authorities would have less work; (3) it would frustrate class conflicts, and the goals of 'imperial' agents and criminals; (4) it would make the work of authorities easier in controlling border territories and cities $^{8}$. In addition to the previously described decree, on June 26, 1955, the Ministry of Home Affairs issued a supplement: those who could not prove their permanent address for two years and were not in work for at least six months must be categorized as people who maintained a wandering and work-avoidant lifestyle. Such individuals were to be provided with black identity cards on an annual basis. This law was not explicitly named as such, but this can be called the first racial regulation of the socialist period the goal of which was to control wandering gypsies.

In 1952 the Public Order Policing Department requested the Criminal Investigation Department to prepare a plan to settle and compel wandering gypsies to work ${ }^{9}$. The starting point of their argument was the stereotype that many gypsies were not taking part in productive work. It is important to note that there were no precise numbers but only exaggerations were used to justify the regulation. The image of the culturally backward, thuggish gypsy was used to rationalize government action. Gypsies were viewed as criminals who were not afraid to rob and kill settled working citizens. It was argued that they lived in shantytowns during the winter but left these places when spring arrived to roam the country. It was claimed that they were not only dangerous from a law enforcement perspective but that they represented a danger to the public health and safety of the majority population: they might carry and spread different infectious diseases.

The idea that this was a racially discriminatory regulation is supported by the statements which were written in the law that regulated the introduction of identity cards ${ }^{10}$. 'Wanderer' was used as a synonym for gypsies and the idea to introduce black identity cards served racial segregation. Since 1948, the beginning of the socialist era, it had been debated whether it was justified to legally acknowledge gypsy as a nationality. But it became a clearly established position by 1961 that in view of their essential difference from Hungarians they could not be acknowledged as a part of the Hungarian nation, therefore

\footnotetext{
8 Barna Gyula Purcsi, “Fekete Személyi Igazolvány És Munkatábor. Kísérlet a Cigánykérdés „Megoldására” Az Ötvenes Évek Magyarországán.,” Beszéló 6, no. 6 (2001): 26-37, http://beszelo.c3.hu/ cikkek/fekete-szemelyi-igazolvany-es-munkatabor.

9 Purcsi "Fekete Személyi Igazolvány És Munkatábor".

${ }^{10}$ Purcsi "Fekete Személyi Igazolvány És Munkatábor".
} 
it was decided to abolish the Cultural Association of Hungarian Gypsies. Furthermore, the Hungarian Socialist Workers Party categorized gypsies as not belonging to any state (or nation) and as being incapable of further development. Race as a terminology never appears in the official documents but with one exception. By 1961 it was decided - perhaps because of the objections from gypsy activist László Mária and members of administrative bodies (Executive Committee of Pest County), and police officers for its racially discriminative nature - that identity cards must be distributed uniformly to all Hungarian citizens and black identity cards must be withdrawn. With this act the unconstitutional racial discrimination of Hungarian gypsies ended at the official state level. However racial discrimination continued in the health discourse: it was argued that gypsies represented serious health dangers to non-gypsies because of their undeveloped living places and their nomadic lifestyle. In the following I will take up the line of debate that continued in Népegészségügy after the Second World War.

\section{Racial Discrimination of Gypsies in the Public Health Discourse}

The tone and themes that were described above on the pages of Népegészségügy continued after the war and discriminative practices were common towards gypsies during the decades of Socialism. I want to start with the debate on the 'gypsy-question' that took place in the articles of József Galambos, János Heicinger, and Ferenc Fellner - all of whom were physicians ${ }^{11}$. In these articles, the authors discussed the health threat that gypsies were thought to represent for the majority population after the war. The basis on which they built their position concerned the relationship between the large numbers of wandering gypsies and those gypsies already settled within villages and cities; it was believed that the latter might accommodate the former thus facilitating the spread of diseases. The attitude of healthcare professionals and police towards gypsies can be demonstrated in the case of Hajdúhadház - a village in Central-Eastern Hungary ${ }^{12}$. Gypsies had been living on the border of the village in shantytowns since the 1940s. In 1947 the village was quarantined because it was suspected that typhus had infected its inhabitants; later they discovered that it was not typhus but malaria. First it was suspected by physicians that the gypsies spread typhus, but when they realized that it was malaria, they destroyed the surrounding environment in an effort to kill the mosquitoes and their larvae. Despite this action, the majority population objected to leaving gypsies and their shanty-towns intact - they believed that they were still potentially dangerous to public health so the gypsy

${ }^{11}$ Dupcsik, A Magyarországi Cigányság Története, 143-144.

${ }^{12}$ Dupcsik, A Magyarorszáai Cigányság Története, 145. 
families (331 people) were relocated and their huts demolished all under the supervision of the authorities.

Another significant practice that was indicated as an urgent public health need was the continuous forced bathing of gypsies living in settlements on the borders of towns and villages during the Socialist period. It is significant as more than half of the gypsy population of Hungary was forced to take part in these bathings. It was introduced in the $1940 \mathrm{~s}^{13}$ but became widespread during the 1950s continuing until the end of the $1980 \mathrm{~s}^{14}$. Forced bathing meant that health officers regularly inspected settlements. And with the help of the police, soldiers and gypsy leaders, health officers forced gypsies into big tents where they were forced to shower with cresol soap and be fumigated with DDT both of which were used for disinfection against lice; it was argued that typhus was spread mostly through lice living on the human body. Health officials typically surrounded and quarantined settlements, pitched an army tent, and methodically forced the inhabitants into the showers. In these tents, healthcare officials could bathe a hundred individuals per hour. Not only were these practices humiliating, but both disinfectants used are harmful, and DDT was banned accordingly in 1968 by the United Nations Food and Agricultural Organization (FAO); Hungary was among the first countries to sign the treaty. The process of disinfection was more about the exertion of power over the gypsy ethnic minority by the authorities (and those majority Hungarians who helped in this process); in addition to this, they usually depilated the body hair of all that which added to their humiliation. These practices were far from medical necessities as gypsies without medical issues were also forced to take part and, importantly, no non-gypsy Hungarians were checked for lice or any other condition and none of the majority Hungarians were forced to take part in communal bathing. What Bernáth and Polyák aptly indicate is the change in the rhetoric

${ }^{13}$ The continuity of atrocities against gypsies can be traced back to 1940 as Péter Bernát and Laura Polyák (2001) show through the interview that they conducted with the physician abbreviated as K.P. and what is evident from their account is that the practices that were coated as public health measures eased off during the socialist period. The drastic actions that were taken against gypsies is illustrated through the interview with doctor K.P. He tells a story about a village in Transylvania where he worked as a military physician after the annexation in 1940. It was thought that typhus was spread to the soldiers from a village and particularly from the settlement of gypsies. It was ordered to relocate everybody from the shantytown but before that it was mandatory to depilate all of the inhabitants and disinfect them. As a final act of the public health measures that needed to be taken - he claimed - they burned down the huts of gypsies and forced them to move out from the village to an uninhabited territory between villages.

${ }^{14}$ Péter Bernáth and Laura Polyák, "Kényszermosdatások Magyarországon," Beszélo" 6, no. 6 (2001): 38-45, http://beszelo.c3.hu/cikkek/kenyszermosdatasok-magyarorszagon; Dupcsik, A Magyarországi Cigányság Története. Történelem a Cigánykutatások. Tükrében, 1890-2008. 
and somewhat in the practice in comparison to the Interwar years and Second World War, but the general racially biased attitude remained during the socialist period and continued after the transition as well ${ }^{15}$.

\section{Gypsies at the Center of Socio-political Interest}

It was in the 1960s, that the gypsies became the object of socio-political interest. To underscore this point, two state statutes can be referenced (1961 and 1979) that defined the areas that needed to be tackled so as to improve the living standards of gypsies and thus their integration into society. The areas requiring progress were educational, employment, housing, and hygienic conditions. Mária Komlósi and her colleagues ${ }^{16}{ }^{17}$ discussed the significant improvements that had been made in the living standards (especially regarding their living conditions and their health) of gypsies, in the period between 1960 and 1985; but their quality of life was far less than that of the non-gypsy population. For example, the sociologist István Kemény, remarks that the practices in Baranya County were inconsistent with central ideas about integration, there, it transpired that new gypsy slums emerged as gypsies moved into smaller villages from their illegal settlements ${ }^{18}$. Though this was the case in general, researchers recognized that gypsies were not a homogenous mass, but a layered community; its layers defined by socio-economic status, educational background, geographical location, gender, and their ethnic identities.

\section{Gypsy Identity Perceived as a Factor that Affects Birth Rates}

Ethnic identity as a variable for reproductive results became relevant for medical reasons in the 1960s and 1970s. Initially, researchers were looking for various factors that negatively affected the outcome of pregnancy. They listed factors, such as "the alcoholism of the pregnant woman, the size of the womb, four or more miscarriages" but in addition to these problems, factors such as "lower educational level, unhealthy living conditions,

15 A recent example that they gave is racial segregation in schools. In 1997 in Tiszavasvári - a town in North East Hungary - the school-leaving ceremony was separately held for gypsy and non-gypsy children because of public health reasons. The school was sued, and the court fined the municipality. The municipality had to pay every gypsy family for racial discrimination (Bernát and Polyák 2001).

${ }^{16}$ Mária Komlósi et al., “A Cigány Lakosság Egészségi Állapota I. Rész,” Népegészségügy 66, no. 5 (1985): $305-7$.

${ }^{17}$ Mária Komlósi et al., “A Cigány Lakosság Egészségi Állapota II. Rész,” Népegésqségügy 66, no. 6 (1985): 339-41.

${ }^{18}$ Komlósi et al., “A Cigány Lakosság Egészségi Állapota I. Rész,” 305. 
gypsy status, and disadvantaged social circumstances" were also connected to premature birth $^{19}$. József Kóbor and his colleagues argued that the most important factors that influenced premature birth were "nutritional possibilities, direct antecedents of birth, hygienic conditions, social-cultural environment, age and familial status, nurturing, and general health."

Their study is important because it is one of the earliest public health studies (focusing on birth statistics) that shifts concerns from various factors onto two overlapping differences. Researchers found that certain characteristics appear together thus they decided to exclude certain factors and focus on those that seemed to reflect multiple problems at once. Such factors were for example 'disadvantaged social circumstances;' researchers understood that these regularly appeared with poor nutritional possibilities and substandard housing conditions which led to poor health outcomes for the members of the group. They similarly noticed that being gypsy (or in their words "gypsy status") co-exist with other factors. They termed these "encompassing factors" and began to analyze how these encompassing factors affect birth outcomes. They found that being gypsy resulted in a high percentage of premature births (when they removed the gypsy results from their sample they noticed 2 percent fewer premature births in comparison to average). In addition to this, they further removed the category of smokers and together with the gypsy category the number of premature births fell to half of the average $\mathrm{e}^{20}$. In sum, they concluded that by removing factors such as gypsy, smoker, hygienic housing conditions, and abortion, only 6.7 percent of the remaining mothers gave birth prematurely which was interpreted by them as a favorable result even in comparison to international standards. Thus, they argued that it is important to further analyze the complex nature of these social, economic and biological factors that contribute to these results.

\section{Statistical Figures on Pregnancy and Birth Rates among Gypsies}

When discussing gypsy pregnancies scholars highlighted the factors that influenced the birth rates of gypsy pregnancies ${ }^{21}$. For example, bad housing conditions, poor hygiene conditions, effects of smoking, inaccessibility to prenatal care because of geographical distances (there were no healthcare workers in the settlements or in the sample villages).

\footnotetext{
${ }^{19}$ József Kóbor et al., “A Terhesség Kimenetelét Befolyásoló Faktor Néhány Analaízise,” Népegésæșégügy 53, no. 5 (1972): 282-86.

${ }^{20}$ Kóbor et al., “A Terhesség Kimenetelét Befolyásoló Faktor Néhány Analaízise,” 285-286.

${ }^{21}$ Mihály Horváth, István Piszér, and Zoltán Nagy, "Alacsony Születési Súlyra És Koraszülésre Hajlamosító Tényezők (Cigány Terhességekre Vonatkozó Adatok),” Népegész̧égügy 53, no. 5 (1972): 287-90.
} 
Also, unfavorable nutritional possibilities, a high number of abortions, frequent medical conditions (hypotonia, anemia, cystopyelitis, helminthiasis), many and frequent pregnancies per woman, and the growing numbers of young mothers. As a possible solution, Mihály Horváth and his colleagues suggested distributing more information about personal healthcare as well as contraceptive methods, but at the same time they emphasized the need for institutional development in the region. Without considerable developments in medical offices and medical staff, and without the conditions to access hospitals the health statistics of gypsies would not change.

Others began from the observation that the number of live births increased as a consequence of the enactments of population policy decrees. New contraceptive technologies were introduced and thus the traditional form of birth control (i.e. abortion) began to decrease. However healthcare workers recognized that these new technologies unfortunately were not accessible to people living in economically and socially marginalized communities $^{22}$. Bodnár for example analyzed the situation of gypsies in Szabolcs-Szatmár counties because researchers had discovered that the gypsy population offset the livebirth statistics in this part of the country. Bodnár explained that the rate of gypsies to the majority population was 6.9 percent but in Szabolcs-Szatmár 18 percent of every 5th born (and above) children died. This was explained by the low-income, low-education, low-level of healthcare conduct, and poor living conditions of gypsies - although their housing conditions started to change in the 1960s, their reproductive health results did not follow rapidly.

Researchers compared large families (with four or more children) of gypsy and non-gypsy backgrounds and found that those who were educated used some form of contraception while this was less true of those with a limited education. They found in their comparative study that most gypsy families (62 percent) used some form of contraception (pills and $\mathrm{IUE}^{23}$ ). In 1960 there were 11041 large families and this number decreased to 4919 by 1977 which was interpreted as good progress. However, regarding these results, Bodnár also placed emphasis on the fact that the practices of people who belonged to the lowest economic strata did not change, thus it prompted healthcare professionals to seek ways that would help their reproductive decisions making ${ }^{24}$. One of the examples that Bodnár gave was the regulation of IUEs (officially regulated by the

${ }^{22}$ Lóránt Bodnár, "Az Elmaradott Néprétegek Családtervezésével Kapcsolatos Tapasztalataink Szabolcs-Szatmár Megyében,” Népegészségügy 61, no. 3 (1980): 175-78.

${ }^{23}$ Intrauterine loop.

${ }^{24}$ Bodnár, "Az Elmaradott Néprétegek Családtervezésével Kapcsolatos Tapasztalataink Szabolcs-Szatmár Megyében,” 177. 
6/1977 Health Ministry decree): the placement of IUEs is the right and responsibility of healthcare institutions. He argued that perhaps it would have been more efficient to allow the placement of IUEs in other locations, because of those gypsy and non-gypsy women who had large families and lived in remote settlements or villages. These women perhaps would opt for this contraceptive method if they could have access to it in their villages but they would not travel 30 to 50 kilometers to have it fitted ${ }^{25}$. Thus, it was underscored that helping large families and the gypsy population should be one of society's priorities.

Similar results were found in succeeding studies. When Bodnár and his colleagues discussed newborn rates in Szabolcs-Szatmár county they concluded in their analysis that the gypsy population - although they were 7.3 percent of the population - accounted for 14 percent of live births and 25 percent of stillbirths ${ }^{26}$. They emphasized that "the unfavorable characteristics of gypsy pregnant women and newborns aggravating the difficulties of the healthcare system to function effectively, they need special tasks and special provisions," in addition they pointed towards constant health education, and the need for cooperation among authorities (social, economic, cultural) in order to execute care work. In my view, it is an important historical fact that healthcare workers have tracked mortality rates of gypsy newborns since $1962^{27}$. Bodnár and his colleagues explained that it was possible to understand that gypsy newborn mortality rates were always higher than non-gypsy newborn mortality rates. From these records they inferred that the trend was downwards - in the early 60s it was 7-8 percent above the non-gypsy results while by the 80 s this became only 1.5 percent - but it remained one of the key problems that the county had to face. Ethnic categorization from a medical perspective was an important tool that enabled researchers to understand health related differences between gypsy and non-gypsy communities, which was an important step towards overcoming health inequality.

It was noted that with these statistics they could understand how gypsies and other "undeveloped" strata held back healthcare institutions from delivering good results. And they also emphasized that their reproductive rates were higher than the average, thus healthcare workers would have to face further issues; it was not only the question of infant mortality, but the frequently sick and underdeveloped children who represented

${ }^{25}$ Bodnár, “Az Elmaradott Néprétegek Családtervezésével Kapcsolatos Tapasztalataink Szabolcs-Szatmár Megyében,” 177-178.

${ }^{26}$ Lóránt Bodnár et al., “A Cigány Nők Terhességeinek Társadalmi, Demográfiai Jellemzői Szabolcs-Szatmár Megyében. I. Anyag És Módszer,” Népegészségügy 62, no. 1 (1981): 30-34.

${ }^{27}$ Bodnár et al., “A Cigány Nők Terhességeinek Társadalmi, Demográfiai Jellemzői Szabolcs-Szatmár Megyében. I. Anyag És Módszer,” 32.

Pro\&Contra 1 (2019) 47-66. 
further problems ${ }^{28}$. They suggested that not only biological causes were important in understanding mental backwardness but social-environmental factors as well - in other words, that many of these children were raised in environments where they scarcely had enough stimuli to help in their development. This in turn would make their education and social integration very difficult. They essentially concluded that the cultural level of gypsies determined their social opportunities; their cultural habits, their large families, their lack of education, their environmental factors - all contributed to reproducing their present detrimental situation. Thus they argued that medical professionals by exploring the field of infant health could contribute to the much-needed change that would help gypsy communities to better healthcare.

\section{Comparing the Biological Characteristics of Gypsy and Non-gypsy Moth- ers and Infants}

It can be claimed that one of the significant starting points in the comparative work of gypsy and non-gypsy biological characteristics is the articulation of racial difference: "undoubtedly, within the country's population gypsies belong to a sub-racial category" 29 Bodnár further explained that newborn data proved that there was material ground for differences that were understood to be the consequences of their racial difference, and to their socio-economic situation. The idea that gypsy women have different biological determinants in comparison to non-gypsy women and thus these biological factors would decisively influence their birth results was compatible with the view on racial difference. Although in their study, Bodnár and his colleagues rejected the idea that there are essential biological differences, they maintained that the biological condition of gypsy mothers influenced their births results. This biological condition however, was determined by their socio-environmental conditions and thus the unfavorable birth results (premature birth, low-birth weight, early and late infant mortality rates) could be explained by their socially and economically marginalized situation in society ${ }^{30}$. In addition to these issues, they stressed the problem of short rest periods between pregnancies and number of miscarriages as factors that also influenced the increase in infant mortalities. Infant mortality

${ }^{28}$ Bodnár et al., “A Cigány Nők Terhességeinek Társadalmi, Demográfiai Jellemzői Szabolcs-Szatmár Megyében. I. Anyag És Módszer,” 32-33.

${ }^{29}$ Lóránt Bodnár, “A Cigány Nők Terhességeinek Társadalmi, Demográfiai Jellemzői Szabolcs-Szatmár Megyében. IV. A Szociális-Gazdasági Tényezők Szerepe,” Népegészségügy 62, no. 4-5 (1981): 308.

${ }^{30}$ Lóránt Bodnár et al., "A Cigány Nők Terhességeinek Társadalmi, Demográfiai Jellemzői Szabolcs-Szatmár Megyében. III. Biológiai Tényezők; Az Anya Kondíciója,” Népegészségügy 62, no. 1 (1981): 40-43. 
rates are considered to be important markers for determining the economic standards of a society $^{31}$.

Bodnár highlighted that after the analysis of the comparative data, he discovered that those gypsy mothers who were living in good socio-economic conditions gave birth to infants whose biological characteristics came close to the average non-gypsy birth results ${ }^{32}$. He came to the conclusion after a brief theoretical experiment, in which he presupposed better conditions for gypsy parents, and found that if they were living in better conditions (both parents would be in employment, for example) their infant mortality rate could drop by 20 percent. But at the same time he maintained that there are genetic factors understood as racial differences - that could play a role in determining birth weight, or their more frequent premature birth rates. However, Bodnár maintained that unless all of the socio-economic factors were levelled it was pointless to presuppose that birth results are solely genetically determined. Bodnár shared the position of the $\mathrm{WHO}$ - published in 1965 - that questioned the idea that the birth weight of newborns is solely racially/ethnically determined. He summarized the WHO statement that sided with the idea that there are differences in birth statistics within one ethnic/racial group. Socio-economic status has a considerable influence on these results thus it can be inferred from their results that there are ethnic/racial differences observed, but that these were observed in disparate circumstances and if socio-economic differences are not eliminated biological differences cannot be linked to race. Hence, I think Bodnár implied, it is important to track birth results more sensitively: not only race/ethnicity, but SES, environmental factors, stress factors, lifestyle factors, and even epigenetic factors are important in categorization.

Other researchers contributed to this strand of comparative health research on gypsy populations located in other geographical areas. Raffael Szabó and his colleagues for example studied the population of Ráckeve in Pest county ${ }^{33}$. They noted that most studies centered on the gypsy populations of Szabolcs-Szatmár counties and Baranya counties; this is why they researched gypsies in the area of Pest. They recorded gypsy birth statistics after 1966; and from this data they analyzed live birth rates, still-birth rates, perinatal and infant mortality rates, birth weight, and sex ratio. They observed that gypsy women gave birth to 2 to 3 times more children in comparison to non-gypsies. In addition to this, they noticed that the average birth weight of gypsy newborns was 300 grams less than non-gyp-

31 Bodnár, “A Cigány Nők Terhességeinek Társadalmi, Demográfiai Jellemzői Szabolcs-Szatmár Megyében. IV. A Szociális-Gazdasági Tényezők Szerepe,” 308.

${ }^{32}$ Bodnár, "A Cigány Nők Terhességeinek Társadalmi, Demográfiai Jellemzői Szabolcs-Szatmár Megyében. IV. A Szociális-Gazdasági Tényezők Szerepe,” 310-312.

${ }^{33}$ Raffael Szabó, Béla Raffay, and Béla Rex Kiss, “A Ráckevei Járás Cigány Lakosságának Születési És Csecsemőhalálozási Adatai 1966-1982,” Népegészségügy 65, no. 1 (1984): 23-28. 
sy infants. Based on these data, the dominant understanding was - for a long time - that a large percentage of gypsy newborns were born with low-birth weight. The average birth weight of non-gypsy newborns was used as the standard comparative point. It was only later recognized that biological differences between gypsy and non-gypsy mothers played a defining role in the birthweight of their children. Szabó and his colleagues recalled that studies were compared in which results underscored the fact that those mothers whose weight was lower gave birth to children with lower birthweight. They found it important to highlight that the average weight and height of gypsy mothers in comparison to non-gypsy mothers is lower thus it was a mistake to consider gypsy newborns less mature than non-gypsies. It was argued that mothers decisively influence the weight of newborns - the weight of fathers was not considered important at this point - and also exogenic factors such as environment, workplace, lifestyle amongst others, play a crucial role. Thus their standpoint was that the maturity of gypsy newborns must be defined from the perspective of their average height and weight ratio. This could help healthcare professionals (gynecologists, obstetricians, pediatricians) to identify a more precise dividing line (than the arbitrarily identified 2500 grams) between low-risk and high-risk newborns ${ }^{34}$. Their suggestion to identify the threshold for gypsy newborns at 2300 grams was based on the WHO directive that advised a lower threshold for Indian and Chinese newborns because of their racial difference in comparison to Caucasians. In line with the above standpoint, Szabó and Rex Kiss compared mother-infant weight data of 3473 non-gypsies and 300 gypsies and concluded that there is a relationship between the weight of the mothers and the weight of the newborns ${ }^{35}$. According to them ethnic characteristics (general biological difference of gypsies from non-gypsies) are the primary reason why gypsy mothers give birth to lower weight newborns.

Other researchers in contribution to this discussion, added another aspect influencing the average weight of gypsy women in comparison to non-gypsy women, namely the importance of environmental factors. By comparing gypsy mothers and their newborns according to their housing conditions, Lóránt Bodnár and Gabriella Bodnárné Pálosi concluded that those gypsy mothers who lived in slums had a lower weight on average than those living in normal conditions. Thus mothers from the slums gave birth to lower weight newborns. What they also found was that weight gain during pregnancy favorably influenced the birth rates of newborns - however this was rarely the case (it simply did

${ }^{34}$ Szabó et al., “A Ráckevei Járás Cigány Lakosságának Születési És Csecsemőhalálozási Adatai 1966$1982, " 27$.

${ }^{35}$ Raffael Szabó and Béla Rex Kiss, "Vizsgálatok Az Anyai Testsúly Szerepéről a Születési Súly Alakulásában,” Népegészségügy 65, no. 5 (1984): 303-8. 
not occur that often) in the situation of slum dwellers ${ }^{36}$. This information is medically significant since it was understood that these factors influence the birth weight of gypsies and thus put them at risk. They also called attention to the fact that the rate of mental retardation is four times higher in those populations where the weight of the mother and the weight gain of the mother during pregnancy is inadequate. Thus their conclusion was that to change these statistics it was crucial to understand and also to influence lifestyle habits in a positive direction that could favorably influence the general health of gypsies.

\section{Conclusion}

Public health measures that had been taken by the state were initiated by the racial fear that gypsy settlements encourage diseases that will affect non-gypsy citizens. This fear was articulated primarily along the lines of class and ethnic identity. It was understood by healthcare professionals and officials that gypsies represented a health risk for those working-class citizens who were in contact with them by nature of their living environments or workplaces. Thus it was suggested that their living environment be changed; so the state started to forcefully relocate gypsy communities into cities during the 1960s. Another important, albeit racially discriminatory action that continued throughout the socialist period was the forced bathings of gypsies living in settlements. These had long lasting psychological and health impacts on gypsy citizens because they had to endure these communal bathings in which they were not only humiliated but exposed to carcinogenic detergents that potentially could have caused long lasting healthcare problems. The state has not compensated the members of gypsy communities since that time.

The other central public health question, after handling the issue of contagious diseases, was the problem of birth rates. It was discovered that birth rates were negatively affected by the low health standards of gypsies (substandard living environment, inadequate diet, unemployment), and thus structural changes were necessary to attain better birth rates in the country. Research that focused on gypsy birth rates and birth results indicated that the initial comparative standards (comparing birth weights of newborns to the average of non-gypsy newborns for example) were not effective, thereby producing imprecise data. Many factors contributed to birth weight differences, and thus the introduction of an ethnic variable was interpreted as a useful category that could help healthcare workers in establishing precise databases on newborns. Thus this knowledge was not only useful for the medical staff, but important also to gypsy parents, in order

\footnotetext{
${ }^{36}$ Lóránt Bodnár and Gabriella Bodnárné Pálosi, "A Cigány Terhesek Testsúlya És Terhesség Alatti Növekedése,” Népegészségügy 66, no. 1 (1985): 26-27.
} 
to influence their children's development. Hence, it was suggested that ways be found to distribute information to the members of these communities so that they would be able to ensure the health of their newborns. It can be argued that the ideas of eugenics were evident within the state supported healthcare work of the time. While in the case of the management of contagious diseases, with forced bathings and forced relocation, the state aimed at controlling members of the majority non-gypsy population. The goal was to ensure safe public spaces from a public health perspective that would contribute to better living standards and thus would help reproduction. In the discussion centered on reproduction the main focus was on healthy newborns and ensuring that fewer children would be born with disabilities. I understand this also to be a eugenic discussion, as the primary motivation to control these processes was coming from a utilitarian economic perspective, a perspective at the heart of early eugenic discussions. 


\section{References}

Bernáth, Péter, and Laura Polyák. "KÉNYSZERMOSDATÁSOK MAGYARORSZÁGON.” Beszélol" 6, no. 6 (2001): 38-45. http://beszelo.c3.hu/cikkek/kenyszermosdatasok-magyarorszagon.

Bodnár, Lóránt. “A Cigány Nők Terhességeinek Társadalmi, Demográfiai Jellemzői Szabolcs-Szatmár Megyében. IV. A Szociális-Gazdasági Tényezők Szerepe.” Népegészségügy 62, no. 4-5 (1981): 308-14.

—_. "Az Elmaradott Néprétegek Családtervezésével Kapcsolatos Tapasztalataink Szabolcs-Szatmár Megyében.” Népegészéégügy 61, no. 3 (1980): 175-78.

Bodnár, Lóránt, Györgyné Babosi, Ferencné Batári, and Györgyné Páll. “A Cigány Nők Terhességeinek Társadalmi, Demográfiai Jellemzői Szabolcs-Szatmár Megyében. III. Biológiai Tényezők; Az Anya Kondíciója.” Népegészségügy 62, no. 1 (1981): 40-43.

Bodnár, Lóránt, Györgyné Babosi, Ferencné Batári, Györgyné Páll, and Lászlóné Szalivasán. "A Cigány Nők Terhességeinek Társadalmi, Demográfiai Jellemzői Szabolcs-Szatmár Megyében. I. Anyag És Módszer.” Népegészségügy 62, no. 1 (1981): 30-34.

Bodnár, Lóránt, and Gabriella Bodnárné Pálosi. “A Cigány Terhesek Testsúlya És Terhesség Alatti Növekedése.” Népegészségügy 66, no. 1 (1985): 24-27.

Dupcsik, Csaba. A Magyarországi Cigányság Története. Történelem a Cigánykutatások Tükrében, 1890-2008. Budapest: Osiris Kiadó, 2009.

Horváth, Mihály, István Piszér, and Zoltán Nagy. "Alacsony Születési Súlyra És Koraszülésre Hajlamosító Tényezők (Cigány Terhességekre Vonatkozó Adatok).” Népegészségügy 53, no. 5 (1972): 287-90.

Kóbor, József, Gyula Bédi, Nándor Thán, and Jenő Tényi. "A Terhesség Kimenetelét Befolyásoló Faktor Néhány Analaízise.” Népegészségügy 53, no. 5 (1972): 282-86.

Komlósi, Mária, Edina Knáb, Erika Szikszay, and Jenő Tényi. “A Cigány Lakosság Egészségi Állapota I. Rész.” Népegészségügy 66, no. 5 (1985): 305-7.

——. "A Cigány Lakosság Egészségi Állapota II. Rész.” Népegészségügy 66, no. 6 (1985): 339-41. 
Purcsi, Barna Gyula. “Fekete Személyi Igazolvány És Munkatábor. Kísérlet a Cigánykérdés „Megoldására” Az Ötvenes Évek Magyarországán.” Beszélő 6, no. 6 (2001): 26-37. http:// beszelo.c3.hu/cikkek/fekete-szemelyi-igazolvany-es-munkatabor.

Szabó, Raffael, Béla Raffay, and Béla Rex Kiss. "A Ráckevei Járás Cigány Lakosságának Születési És Csecsemőhalálozási Adatai 1966-1982.” Népegészségügy 65, no. 1 (1984): 23-28.

Szabó, Raffael, and Béla Rex Kiss. "Vizsgálatok Az Anyai Testsúly Szerepéről a Születési Súly Alakulásában.” Népegészségügy 65, no. 5 (1984): 303-8. 